\title{
York, Alcuin, and Sir George Newman
}

\begin{abstract}
The history of medicine can give insights into past achievements and provide knowledge and even inspiration, a valuable commodity for young students and all doctors. The contribution of Alcuin of York to basic education, and its appreciation by Sir George Newman, medical officer of health and first Chief Medical Officer of the UK in 1919, is recalled. Newman's Quaker education at Bootham School, his views on the main principles of such an education, as well as his influence on its establishment are summarised. A liberal education for doctors is important and knowledge and inspiration from the past may be one factor in enhancing morale.
\end{abstract}

For a number of years, the British Paediatric Association and more recently the Royal College of Paediatrics and Child Health, have held many of their annual meetings at the University of York. The name Alcuin is therefore familiar to many paediatricians as a hall of residence has been named in his honour by the University. Perhaps they are not so familiar with the role of Alcuin as a pioneer of education in Britain and Europe.

Some paediatricians may also be familiar with the name of Sir George Newman, the first Chief Medical Officer of the UK, ${ }^{1}$ but now regarded as one of the public health pioneers of paediatrics in this country, as the emergence of paediatrics as a medical specialty has been linked to concern about population problems in children. ${ }^{2}$ His contribution to child health was particularly related to the publication of his book, Infant mortality: a social problem, in $1906 .{ }^{3}$ In addition, through his work at the Board of Education, he too made a notable contribution to the health and well being of children in the UK by improving their education.

In 1923 Newman, as a former pupil, gave an address at the celebration of the centenary of Bootham School, the Friends school in York. ${ }^{4} \mathrm{He}$ introduced his address with a lengthy tribute to Alcuin of York.

The purpose of this occasional report is to draw attention to the work of Alcuin and how such historical knowledge was regarded to be so important by Newman, and to use such knowledge as an illustration of the educational value of the History of Medicine.

\section{Alcuin of York}

Alcuin —educator, poet, and cleric —was born in York in 735 of a noble family. As Newman tells us, the year of his birth coincided with the "death of Bede, who in the last months of his life had written a long letter to his disciple Egbert, first Bishop of York, then Headmaster of the Cathedral School, urging the importance of education in the building up of church and nation". Alcuin later attended the school and became its headmaster and the keeper of its famous library. Interestingly Alcuin described the education received as being not only in the traditional classics, but also in elements of music and of natural science. The school was designed to teach boys of "the sun and moon and sky and planets seven, the cause of storms, of earthquake shocks, and the

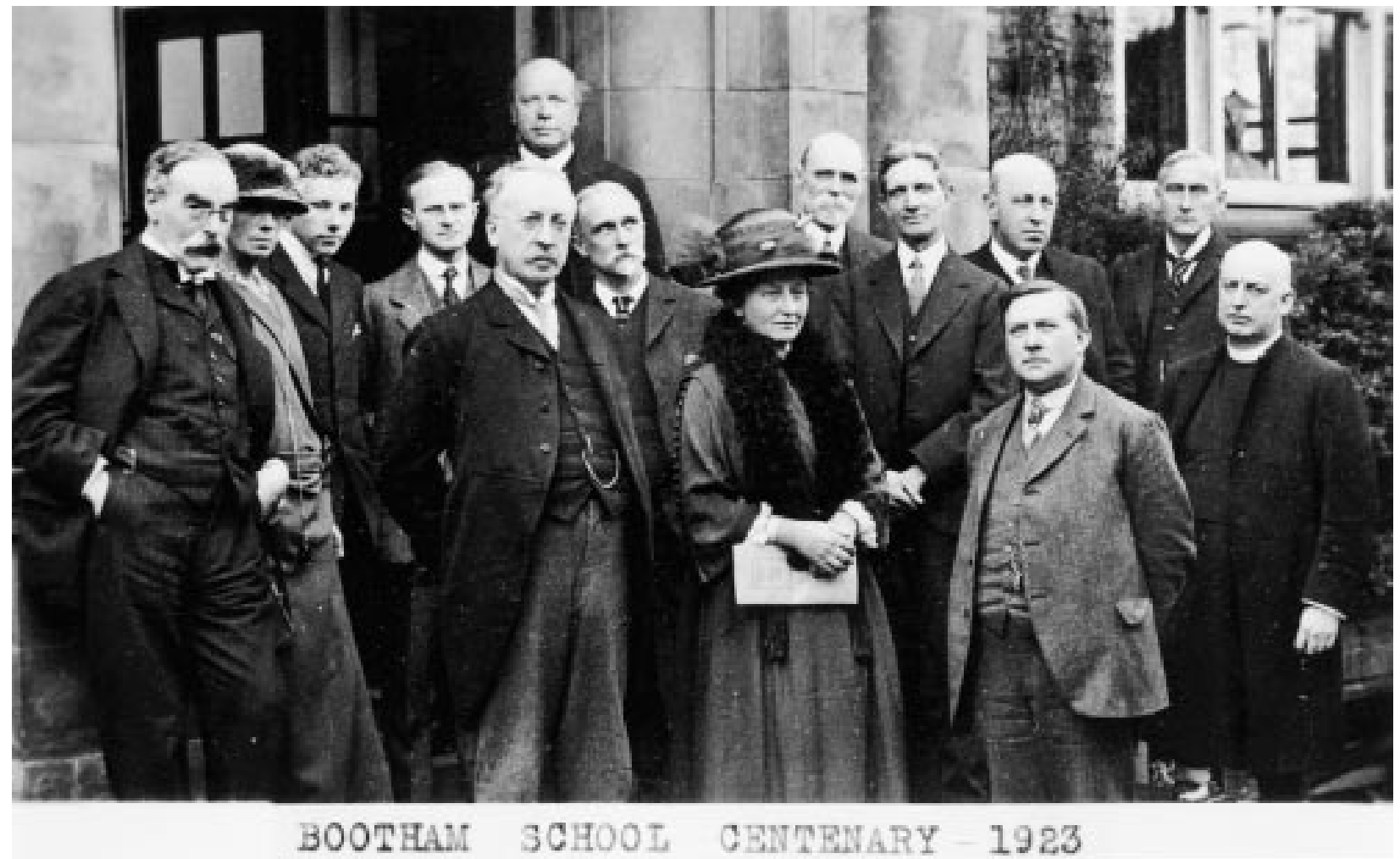

Figure 1 Bootham School Centenary, 1923. Sir George Newman (in tail coat) with staff and visitors to the school. 
distinctions between man and beast and bird". A principle held in much esteem was "to know the reason of things", both in classics and what he called "physics".

In 782 Alcuin left York to take up duties at the court of Charlemagne in Aachen as Master of the Palatine School, a school consisting of the younger members of the royal family and the sons of the chief nobles. The King had gathered the leading English, Irish, and Italian scholars of the age. Alcuin systematised the curriculum, and raised standards of scholarship. Most notably he encouraged the study of liberal arts for better understanding of spiritual doctrine. Within 10 years Alcuin had persuaded the King to adopt a graded system of free education. Aachen at this time became a centre of revival of learning, known as the Carolingian Renaissance. ${ }^{5}$

He left the court of Charlemagne to become Abbot of St Martin at Tours in France in 796. There he fostered the love of books and as Bishop Brown in 1908 lyrically described, brought to France "the flower of Britain, that the garden of Paradise be no more confined to York" ${ }^{6} \mathrm{He}$ died in 804 desiring that even if his body must repose elsewhere his soul should rest in York. His life in fact embodied certain contradictions. ${ }^{5}$ By the end of his life he had acquired a great reputation for holiness and also was clearly a leader of the church, yet he is not included in the canon of saints nor did he ever rise above the position of deacon-he never became a priest.

Newman declared that Alcuin had three core principles. ${ }^{4}$ First was the advancement of the State by holy learning and by holy life - that is, education and religion. Second, education must seek to teach comprehension rather than repetition, reinterpreting the truths of mankind in the language of every age, and must also seek, as the Latin poet Vergil had said, the cause of things and know their reason. Third, the means of education in a state must be wisely and liberally furnished if ideals are not to die and hopes perish.

Newman interpreted from this that a liberal education could not be obtained only from the study of classics, but "necessitated the practice of the arts and crafts, the breadth of Humanism, and the spirit and method of science". ${ }^{4}$

\section{Quaker education}

Newman saw the Quakers as descendants of Alcuin in these matters. He referred to "a big, strange and solemn man, with piercing eyes being hustled out of York Minster one snowy Christmas morning in 1651 for proclaiming the fact that the 'people lived in words' instead of fruits". ${ }^{4}$ They were professors not possessors. This was George Fox, the founder of Quakerism, the Society of Friends. Fox was later to recommend that the sons of Friends be educated "in whatsoever things were civil and useful in creation".

Eventually in 1823 a Friends school was established in York, moving to its present site in Bootham in 1846. Newman believed there were four key aspects to a Quaker education such as provided at Bootham.

First was cultivation of the individual boy - that is, the cult of individuality. The aim was to bring each boy to the full measure and exercise of his own capacity, unlike the usual public school production of "its type".

Second was encouragement of leisure time pursuits such as natural history. The formation of the Natural History Society at Bootham in 1834, he saw as in the great traditions of Quakers such as the physician Dr John Fothergill. Newman believed that this would lead, as Charles Darwin remarked, "to a love of science ... industry in observing and collecting facts". Interestingly Newman endorsed the view of Captain Scott of Antarctic fame whom he quoted: "Make the boy interested in natural history if you can; it is better than games". In fact Newman himself had been in the first cricket eleven at Bootham school.

Third was the practice of discipline. By this he meant orderliness without dragooning. Newman commended the example of the schoolmaster who imposed a penalty of writing columns on an offending youth in the following terms: " 7 for eating chocolate; minus 4 , gave me some".

Finally, he put forward the concept of education by contact with the outside world. By this he meant widening horizons to open the eyes of pupils to the wideness of the world and to the greatness of man's mind. Newman saw Bootham School as the intellectual heir of Alcuin and he regarded York as the cradle of English education.

It was at Bootham that Newman himself decided on a career in medicine, the first in his family to do so. In a letter to his aunt in 1887 he tells her of his decision to study medicine and in enthusiastic language says, "What indescribable pleasure it must be to see your patient reviving under your work, under your eye, under your prayers". ${ }^{7} \mathrm{He}$ was never to lose that enthusiasm. It is of interest that in his time many pupils of the school also entered medicine. The emphasis on science and natural history and interestingly on political economy at the school, as well as the Quaker tradition to do medicine, clearly must have influenced Newman in his choice of medicine as a career, and perhaps epidemiology (via political economy) as his special interest.

\section{Conclusions}

It is clear today that the virtues of a liberal education for future doctors continue to require emphasis. History of Medicine, by alerting us to what has gone on before, can both inspire and challenge the medical student and young doctor of today. Indeed an important educational value has been claimed for medical history. ${ }^{8}$ The provision of special study modules in the history of medicine by several British medical schools recognises this. Alcuin's requirement that we must seek the cause of things, underpins the current emphasis on evidence based medicine, but equally his emphasis on the proper provision of resources for education is as relevant for medical schools as it ever has been.

However, Newman's pride in our heritage in this country is closely linked to optimism for the future with sentiments, not often so robustly expressed by doctors today as they were by our first Chief Medical Officer speaking of York in $1923^{4}$ : "This ancient city, grey-walled fortress of our liberties, for two thousand years a home of winning causes which have made England great, with the whisperings and enchantments of its dead past, with its long line of heroes, statesmen, scholars, saints and martyrs ... It would be strange if, nurture in such a home, we had received no nourishment from its age-long experience."

When paediatricians next gather in York, perhaps they could give a thought to Alcuin and his devotee Sir George Newman. Hopefully this knowledge could provide some inspiration so that ideals do not die and hopes perish in today's National Health Service. Could it even be that such knowledge might be one factor raising morale in today's medical profession?

J WALKER-SMITH

The Wellcome Trust Centre for the History of Medicine at UCL,

University College London,

24 Eversholt Street, London NW1 1AD, UK

johnwalker_smith@hotmail.com

Thanks are due to Mrs Margaret Ainscough, Archivist, Bootham School, for access to the school archives.

1 Walker-Smith JA. Sir George Newman, infant diarrhoeal mortality and the paradox of urbanism. Med Hist 1998;42:347-61.

2 Abt A, Garrison FH. History of pediatrics. Philadelphia: Saunders, 1923.

3 Newman G. Infant mortality: a social problem. London: Methuen, 1906.

4 Newman G. A Quaker Centenary. Address delivered at the Celebration of the Centenary of Bootham School, York, 21 May 1923. London: British Periodicals Limited, 1923.

5 Alcuin. Encyclopaedia Britannica. Micropaedia I 1981:211-12.

6 Browne B. Alcuin of York. Bristol, 1908.

7 Newman G to Pumphrey CW, 8 September 1886, Newman Papers, MS Newman G to Pumphrey CW, 8 September 1886 ,
6206/30. Western Manuscripts, Wellcome Library.

8 Cule J. Editorial. Vesalius Acta Internationalia Historiae Medicinae 2001;7:1. 